This article is (c) Emerald Group Publishing and permission has been granted for this version to appear here (http://repository.winchester.ac.uk/). Emerald does not grant permission for this article to be further copied/distributed or hosted elsewhere without the express permission from Emerald Group Publishing Limited. 


\section{Emerald $\begin{aligned} & \text { Housing, Care } \\ & \text { and Support }\end{aligned}$}

\section{Creational narratives for new housing communities: evidence synthesis}

\begin{tabular}{|r|l|}
\hline Journal: & Housing, Care and Support \\
\hline Manuscript ID & HCS-10-2016-0010.R1 \\
\hline Manuscript Type: & Research Paper \\
\hline Keywords: & $\begin{array}{l}\text { New settlement, diocese, major development area, participation, } \\
\text { liveability, narrative }\end{array}$ \\
\hline \multicolumn{2}{|l}{} \\
\hline
\end{tabular}

SCHOLARONE

Manuscripts 


\title{
Creational narratives for new housing communities: evidence synthesis
}

\begin{abstract}
Purpose: This paper reports the findings of a rapid evidence synthesis commissioned by the Diocese of Winchester in England. The remit was to provide an empirical basis for church contributions to large housing community developments. It sought to respond to three questions concerning new community developments. These related to risks and causes of failure; learning from past corporate and intermediate tier interventions at diocesan and equivalent levels by religious denominations; and the transferable learning available from developments described in Community Health and Liveability literatures.
\end{abstract}

Methodology: The review took a purposive approach to sampling evidence from within academic literature, policy and 'think tank' outputs and theological texts. The search was instigated with the use of key words (including New Settlements, Urban Redevelopment, Diocese, Faith and Community), principally within the SCOPUS, NIHR, PUBMED and Google Scholar databases. A pragmatic snowballing approach to relevant references was then employed. The review was undertaken from June to September, 2016.

Findings: Segregation and separation were identified as the main risk for new settlements. Connectivity is required between and across neighbours, ensuring communal access to services, transport and recreation. Communal places where people can come together for conversation and social interaction are identified as contributing significantly to healthy communities. Churches have a particular positive contribution to make here, through a focus on inclusion, hospitality and common values, rather than single faith-based, evangelical approaches.

Practical Implications

The initial effect of the study has been to increase confidence in and awareness of the diocesan contribution. In the longer term the three areas of practice highlighted for enhanced faith based contributions are those of public communications, community integration and civic leadership. An evidence based approach appears to be especially significant in facilitating the latter.

Originality: The importance of 'creational narratives' in defining and making explicit the values underpinning new housing communities, is identified as a singular source of shared motivation for planning and faith agencies.

Article type: Literature and documentary review

Keywords: New settlement, diocese, major development area, participation, liveability, narrative

Acknowledgements: This article arises from a collaboration between the University of Winchester and the Diocese of Winchester in the South of England. The authors would like to express their appreciation of the contribution made to this by the David Williams, the Revd. Canon Bishop of Basingstoke, Professor Simon Jobson and Revd. Canon Nick Ralph of Portsmouth Cathedral. 


\section{Context}

The population covered by Hampshire County Council is the third largest county in England, with a total of 1,353,000 in 2015 (Office of National Statistics, 2015). If the two cities of Portsmouth and Southampton are included a further half million people are added to this figure. The two dioceses of Winchester and Portsmouth extend across the whole territory (and beyond to parts of Dorset and Sussex). Many people see it as a desirable area in which to live, and the demographic pressures on the housing stock are compounded by the comparatively high number of older people. In the first decade of the century, the increase in people aged 65 and over was double the national average, and 1 in 8 homes are now occupied by lone pensioners (Director of Public Health, 2015). The pressing need for new housing is reflected in the projected total of over 99,500 new dwelling units, aggregated from local council intentions, in the County Council's strategic Plans (Hampshire County Council, 2016). These include the proposals for 29 Major Development Areas, with at least 500 planned dwellings in each, in the Winchester Diocese alone.

With very few plans for new buildings other than Assisted Schools this diocese is looking to incorporate these 'new settlements' within its existing framework of parishes and benefices. It expects the latter to include the requirements for social action and enterprise in the new housing settlements to be included in their Missional Action Plans (MAPs). The Bishop of Winchester has mandated these to 'find ways to connect with people who do not naturally turn to the church or see its place in society' (Winchester Diocesan Synod, 2015). As such MAPs are perceived as a means of converting into practice two of the (four) strategic objectives of the Diocese to 'heal, restore and reconcile' communities, and reduce social isolation, through agencies of 'social transformation' and 'good stewardship'. The approach chimes with both emerging town planning theory for new housing communities as 'communicative actions' rather than merely 'physical designs' (Taylor, 1998), as well as the notions of a 'deconstructed church' in which 'relational evangelism' can thrive (Gerardo, 2015 and Brown, 2014).

\section{Purpose}

This context of rapid housing growth, allied to new forms of faith based outreach, led to the Bishop of Basingstoke, and the Reverend Canon responsible for the Portsmouth Board of Social Responsibility and Winchester Diocese Social Enterprise programme, commissioning a rapid evidence synthesis. Its remit has been to provide a sound empirical basis for church contributions to large housing community developments. Specifically, the focus was on identifying 'the formative ideas and stories which can effectively shape good relationships in new settlements'.

The overall stated purpose was 'to promote the common good' through what both dioceses termed 'new mixed economies' of interventions. These are typified by the terms of the Rapid Development Programme under way across 20 Portsmouth parishes 'to adapt social and business techniques' together, so that the potential of churches for bringing 'light, hope and belief to their communities' may be exploited (Portsmouth Diocese Board for Social Responsibility, 2015). Such initiatives reflect the General Synod's commitment to address the decline in urban ministry nationally (The Winchester Deanery, 2016). 


\section{Approach}

The rapid evidence synthesis was undertaken by members of the Health and Wellbeing Research Group at the University of Winchester over a three month period in the summer of 2016. This preceded the three yearly Strategic Review of the Winchester Diocese scheduled for October 2016. The evidence synthesis took the form of a structured background literature and documentary review, with an initial post-2000 time frame to reflect the focus on contemporary sources for understanding changes in community wellbeing and housing practices. A pragmatic snowballing approach to relevant references was adopted, after the initial use and combinations of the following keywords - New Settlements, Urban Redevelopment, Diocese, Faith and Community - with the SCOPUS, PUBMED, NIHR and Google Scholar databases. The initial searches soon indicated that relevant learning was more available in the supplementary findings and material of both past studies and present policies, than as a principal research project topic. The time frame for literature sources, accordingly, was extended beyond 2000, with some of the foundational sources cited in this article pre-dating the Millennium as a result.

Through discussions with the local diocesan advisory group the review was based on three priorities for transferable learning. These priorities were articulated, with a view to specific adapted applications in local practices: such as in the co-development schemes between private and municipal developers in West Basingstoke and the partnership of Sovereign Social Housing and Test Valley Borough Council in Andover. Distilled from the advisory group's initial list of ten topic areas, on the basis of most pressing need, the three priorities were framed as the following research questions:

- Within frameworks for developing social capital in modern civil society what is understood about the risks and causes of failure?

- For local community developments requiring multiple innovations including new housing, what is the relevant learning from past corporate and intermediate tier interventions at diocesan levels by religious denominations?

- What do recent knowledge developments in Community Health and Liveability contribute to good communities in major development areas?

For each of the above the remit for the synthesis included identifying examples and illustrations of good practice. International exemplars could be included. Informed by 'realist review' principles the research task also included the process of identifying, and then locating possible underpinning 'programme theories' or ideas from the accessed data (Pawson, 2013).

\section{Findings:}

Risks and failures

The first findings relate to potential shortfalls identified in response to the first research question. Overwhelmingly the evidence from past recent studies points to separation and subsequent segregation as the main risks for new housing settlements. These outcomes may occur by design or 
by default. For example, In Milton Keynes the 1970's construction of cycle lanes and pathways with high walls and thorn hedges as 'visual screens', between social and private housing neighbourhoods, became associated with increased crime levels rather than improved security. More recently, 'Right to buy' schemes, and the private financing of social landlords, have witnessed a re-distribution of social housing so that over half is now found in the most deprived fifth of localities nationally (Joseph Rowntree Foundation 2016, Department for Communities and Local Government, 2010).

As a result of such misalignments the explicit policy objective of 'urban renaissance' for successive post-Millennium government central planning initiatives has been seen to fail. Instead of a 'New Deal' for sustainable 'Mixed Communities' (Department of Local Government, 1997,) researchers describe ' a neo-liberalizing accumulation of dispossession', with 'instrumental' rather than 'empowered' communities, in which art projects may only add to re-sale values (Macleod and Johnstone, 2012). The overall perception here has often become that of 'state orchestrated gentrification', in the strata of which such as depression and smoking levels are on the increase in elderly and unemployed population groups. Too often individuals in these groups appear to be either left on the margins of new housing developments, or forced by economic pressures to move elsewhere (Popay et al, 2015, Greater London Assembly, 2015).

Particularly in times of relative austerity and vulnerable funding streams, when the future feels precarious, the policy pursuit of more owner occupied development can have negative consequences for public trust and confidence (Department of Communities and Local Government, 2010, Straten 2002). Community development in new settlements suffers as a result.

The main finding from the review of past risks and failures is that the value of Connectivity must be maintained through and across critical events in new housing communities. This connectivity applies both to the interior and external designs of buildings, and to the architecture of communication.

Loss is a critical event in old age, and as Canadian residential developments for Co- Care and Congregate Housing now recognise, true Connectivity at this stage of life requires models of neighbourliness and family style living which balance needs for privacy and personal autonomy with communal service provision for transport, recreation, support and health (Novak, 2009; Williams, 2005). Poor housing designs too easily prevent residents relating interactively on a social level within what no longer feels like 'their' neighbourhoods. Localities can become seen and experienced as alien and hostile as a result.

\section{Findings:}

\section{Diocesan intermediate tier}

The data collected in relation to the second research question confirmed that, Aalthough churches have been closely involved with the establishment of 'new settlements' ever since the term was first used in Anglo-Saxon times, little research has been undertaken on the specific role of the diocese itself (Myers, 1986). The strategic intermediate tier of church organisations is most apparent in the literature on recovery and reconstruction, following either natural disasters or the social reengineering triggered by significant civil unrest (Hughes, 2014, Hiroko et al. 2016, Seidman, 2013). 
Much of this is from the United States and has its origins in sources that range from gangsters to hurricanes, with the Chicago model for 'broad based community organising' an exemplar of the former for intermediate tier faith agencies ( Alinsky,1941, Bretherton, 2010). This emphasises the importance of dioceses operating to 'a liberating constitutional order' which promotes ad hoc partnerships across Christian denominations and other faith groups, for the common good.

For the intermediate tier of Christian organisations such a modus operandi requires an appropriate religious justification and perspective. Narrow evangelism and strictly hierarchical management structures are not appropriate. The latter can serve as an obstacle to the decentralisation necessary for decision making which allows new settlements to have sufficient discretion to tailor their facilities to their particular circumstances. The former needs to ensure that the evangelical stance is sufficiently relational to move beyond simply the confines of programmes for house groups of converts and believers (Finney, 2004, Tuttle, 1983); as has been evident in modern China .

Accordingly, one recent Archbishop stresses the need for theological perspectives in an 'Integralist Tradition' that associates itself with help for the poor and opposition to the 'commodifying' excesses of Capitalism (Williams, 2015).

For the diocesan level this can mean that assuming a Comparative Theology stance may be 'uniquely' helpful' in offering the route towards ' a cosmopolitan sharing of common values' in new mixed communities (Newlands and Smith, 2010). The pluralism intrinsic to this position legitimises different sources of both reason and revelation for knowledge and wisdom. For the planning and development of new housing communities it provides a vehicle for combining the secular and the spiritual in the joint pursuit of wellbeing (Hauerwas, 1981).

In practice this means co-sponsorship and support by churches of community centres as modern experiential and environmentally friendly learning centres, which serve as counterpoints to the more calculative agendas and requirements of schools, colleges and other academic performance units. For diocesan management there is no one model or directive, except to avoid middle class capture and ensure a Christian ethos. The local mix of domestic skills training, arts practices, recycling crafts, information technology applications and reflective time slots can as readily be termed an 'Ecospace' as a 'Lifespan' centre, so long as what one international city terms ' bridging social capital' and another 'socially balanced investment' are achieved (Pacione, 2004, Gerardo, 2015, Mason et al, 2015).

The last two terms come from Victoria in Australia, and Scandinavia respectively. They point to the importance for diocesan management of getting the language right. Recent commentators on developments in European Social Policy are of one mind in viewing housing developments as 'communicative actions' or 'conversations' (Taylor, 1998, Gerardo, 2015) in which the right words and terminologies have the potential both to develop and sustain community. For the Winchester Diocese there is much encouragement to be gained from recent studies for its shift away from traditional purely pastoral stewardship towards an 'activating social investment' role (Hausermann, 2012,), This often involves 'variable and highly contingent actor coalitions', and in pursuit of the fidelity required for 'long haul' communities (Stephenson, 2015) the intermediate tier of faith based organisations appears well placed to undertake the 'cognitive mapping of local texts' required (Hiroko et al., 2016). The diocesan leadership is singularly qualified to help ensure that the contemporary imperative for civil society based services is informed and shaped by religious 
aspirations for community, which embrace 'a philosophy of the personal', hospitality and the opportunities afforded by 'social citizenship' (Kirkpatrick, 2001, Dwyer, 2010).

Leadership at the faith based intermediate tier does, however, need to be careful. Use of language can be unwittingly counterproductive. After all, not everybody thinks of the Pilgrim Fathers when the term 'new settlement' is used. For many in both policy circles and poverty traps the words are now often negatively associated with the rights requirements (and vetoes) of 'naturalisation' and 'immigration' (Goodman, 2010). Stigma can result. Similarly to treat community and parish as synonyms can alienate, with European research suggesting the boundaries of the latter are much less appropriate than the 'core_space' characteristics of the former: in which socio-demographic features should be understood alongside administrative structures and political elites that are no longer geographically bound ( Gartner, 2011).

\section{Findings: \\ Community wellbeing}

The last research question brought us to the fundamental issues offo-what makes for a good community in new settlements, and who defines what is 'good'? In terms of major housing developments recent research points to a continuing shortfall in contributions from residents themselves in decisions on planning and development. 'Instrumental' community engagement initiatives are too often perceived as short term tactics and 'housing with care' is biased towards administrative rather than social assessments (Popay et al, 2015). This bias is reflected too in contemporary scales for 'Liveability', in which measures for such as insurance premiums, property prices, crime rates and broadband speeds are prominent.

If this bias reflects the powerful influence of economists and statisticians today, an alternative perspective emerges when reviewing studies from schools of social science academics. Their recent research has been most influential in shaping the policy shift towards what is now termed 'Place based health' (Ham, 2015, The Place-Based Commission, 2016). This has led to the adoption of ten major housing development areas by the NHS as 'healthy new town' demonstrator sites (NHS England, 2016), and the creation of a Centre for Social Action in the Cabinet Office. In contrast to the liveability metrics this Centre draws on a range of empirically based Social Support and Loneliness Scales (e.g.s De Jong Greiveld, 1985, Walshe, 2016), to underpin projects that focus particularly on befriending for older residents and cross-generational integration (Demos, 2015).

The twin track notion of community rights as a key ingredient of good health and health responsibilities as a key ingredient of good community is central to many civil society oriented public service systems in Latin America (Meads, 2007). For example, multi-faceted community health centres providing a spectrum of activities from seniors' choral singing to disability day care, alongside doctors' consulting rooms, are commonplace in the likes of Peru, Bolivia and Brazil, and now have emerging counterparts in the UK's new housing settlements. In the Winchester Diocese, for example, at the Picket Twenty planned development for almost 2000 homes on the outskirts of Andover in West Hampshire, the newly built community centre includes recycled crafts and bistro café classes, in response to locally defined agendas for environmental awareness and cooking skills. 
Such developments reflect the rapid advance in arts practices and have in common the commitment to what Oldenburg (1988) originally termed a 'third place' where people can gather together informally on neutral ground, without status inhibitions, as community - outside the first and second places of home and work where formal roles and expectations have to prevail.

Third places have been closely associated with public health promotion and improvements in more recent studies. Defined as 'great good places that foster community and communication among people' (Jeffres et al, 2007), their benefits for both overall civic welfare and specific gains in such as pain management, depression and hospital lengths of stay have been identified in scientific work led mostly by North American researchers ( Tolbert et al, 2002, Frumkin,2002, Baum and Palmer, 2002,). In such as New Orleans, after its flood disaster, where faith based agencies have helped to 'tailor' responses to local 'places' the findings point to no less than full 'city recovery' and 'restored complete neighbourhoods' through 'grassroots rebuilding' (Seidman, 2013). Back in the NHS in England the psychology of 'enabling environments' is now recognised through an adapted form for community mental health of the individuals' recommended five- a- day fruit and vegetable diet: 'Connect, be active, take notice, keep learning and give' (Foresight, 2008). Many a sermon has had an equivalent spiritual agenda.

\section{Synthesis}

There are four common strands across the three review findings. First, there is the focus on dialogue. In the third places identified, by examining what makes for a good community, conversation always emerges as the main activity (Jeffres et al, 2007). This aligns with the designs for criss-crossing pathways in both the internal and external spaces of new community centres, and the risks of restrictive physical borders identified in the first two reviews. All three emphasise the importance of viewing new housing settlements as reciprocal interactions in which shared stories, anecdotes and values can be expressed orally and often.

Secondly, there is the common notion of major development areas as life giving communities, with their meaning captured in phrases that capture the essence of their enhancing collective identity and being. The words for these phrases are powerful, especially when negatively related to realities of actual relationships, and our reviews each indicate the need for careful and accurate crafting of the vocabulary. At Picket Twenty near Andover, for example, the child care facility sited opposite the community centre is actually termed an 'Egg Nursery'. The names of roads, parks and edifices are important, but even more important is how and who names them.

Thirdly, the reviews highlight the potential positives of faith based agencies and their intermediate management tiers, with local strategic responsibilities, for positive contributions to community development in new housing areas. Promoting participation is always at the heart of these contributions, although the forms and processes such public involvement can take are evidently and necessarily a moveable feast. Recent research points to the need for such faith based inputs to be non-partisan, empathic, and effective in their modern communicative scope. These emerge as the baseline requirements for such as dioceses, as well as other agencies at the intermediate tier of strategic development. 
The final value added contribution revealed through this synthesis, however, comes from pulling the three strands set out above together. This is the provision of what may be termed 'creational narratives' for community in new settlements. The term goes further than the simple 'social investment' narrative characteristic of Scandinavia's new towns, by employing wording which looks to reflect the spirit as well as the social mix of a major housing development. For example, in the Winchester Diocese, at Andover's Picket Twenty new settlement, the secular requirement for 'Considerate Construction' registration is augmented by banner headlines (on the Church Assisted School) for Courage, Love and Trust 'to make a difference' growing together ('in God's world'). Such creational narratives have rich source material in such as the opening chapters of religious texts, including most obviously the Jewish Old Testament. Each, of course, needs to be chosen and articulated in ways that engender participation particular to place.

Implications for Practice

While it is very early to assess definitively the contribution of the evidence synthesis to local practice, it is apparent from diocesan feedback that the findings have enhanced levels of confidence and awareness. More generally, and for the longer term, especially in the context of diocesan and similar faith based organisations' strategic reviews, three areas have been highlighted for future application.

The first is that of public communications. For planners the language and style employed in a range of oral and printed formats is critical: from sales brochures and tender bids to the names of buildings and roads and the titles of residents' newsletters. Altogether these constitute the currency of formative cultures in major development areas, and it is clear that faith based sources can contribute to these through their rich supply of relevant material in relation to such as revival, restoration and, above all, new birth and creation.

Secondly, there is the articulation of faith based values which help shape community integration, backed up by social action with support from such as the local church, mosque or temple. The practice of community care increasingly depends on social enterprises, and faith based agencies are at the forefront in developing community interest companies and their counterparts. Typically these are not partisan but whole community focused. In the Winchester Diocese, for example, the Cathedral's social enterprise is the largest provider of befriending schemes for older people in the county, with over 4000 active volunteers (Ralph, 2015), and the Winchester food bank uses images of loaves and fishes drawn from a New Testament story to promote a universal message of equal shares and common generosity.

Finally, and unexpectedly, the review is a practical resource in the facilitation of effective civic leadership for new housing communities. The suggestion is that, through the review, the provision of evidence has helped to legitimise the contribution of faith based agencies through enabling this to be seen as both 'reason and revelation' (Williams, 2015). The results are significant. They include the personal mentoring of local chief officers by priests and the shift in planning proposals from the physical to social capital developments in North Hampshire. The modern church is no longer understood as a building but appreciated more as a house group based resource for positive relationships. 
Conclusion

In the context of new mega cities and escalating urbanisation recent theological writers have located community wellbeing in the context of core human rights, which depend on 'stable environments of compassionate construction' (Newlands and Smith, 2010). For them this is now the 'transformative dream' of a 'Hospitable God' today. While not all will agree with this expression, the aspiration does point to the high level of motivation and, indeed, inspiration that can be accessed if the appropriate creational narratives are articulated, and such faith based organisations as dioceses effectively partnered in new housing community developments.

\section{References}

Alinsky, S. (1941). "Community analysis and organization". American Journal of Sociology, Vol. 46, No. 6, pp. 797-808.

Baum, F. and Palmer, C. (2002), "Opportunity structures: Urban landscape, social capital and health promotion in Australia," Health Promotion International, Vol. 17, No. 4, pp. 351-361.

Bretherton, L. (2010), Christianity and contemporary politics. John Wiley, New York, NY.

Brown, M. (Ed.). (2014), Anglican Social Theology today, Church House Publishing, London, UK.

De Jong-Gierveld. (1985), "The development of a Rasch-Type Loneliness Scale”, Applied

Psychological Measurement, Vol. 9, No.3, pp. 289-299.

Department for Communities and Local Government. (2010), "Evaluation of the Mixed Communities Initiative Demonstration Projects", available at:

https://www.gov.uk/government/uploads/system/uploads/attachment data/file/6360/1775216.pd f (accessed 16 June 2016).

Diocese of Portsmouth. (2016), "Rapid Development Programme". http://portsmouth.anglican.org/what we do/social justice/rapid development programme/ (accessed: 19 July 2016).

Director of Public Health. (2015), Public Health in Hampshire. Hampshire County Council, Winchester, UK.

Dwyer, P. (2010), Understanding Social Citizenship, Policy Press, Bristol, UK.

Edwards, M.(2001), "City design. What went wrong in Milton Keynes? " Journal of Urban Design, Vol. 6, No. 1, pp. 87-96.

Finney, J. (2004), Emerging Evangelism. Twisleton Publishing, Dartford, UK.

Foresight (2008). "Mental capital and wellbeing. Making the most of ourselves in the $21^{\text {st }}$ century". Final Project report .The Government Office for Science, London. Executive summary available at: 
https://www.gov.uk/government/uploads/system/uploads/attachment data/file/292453/mentalcapital-wellbeing-summary.pdf (accessed 10 June 2016).

Frumkin, H. (2003), "Healthy places exploring the evidence", American Journal of Public Health, Vol. 93, No. 9, pp. 1451-1456.

Gartner, S. (2011), "Corporations and regions: Capturing multiple vicinities in European regions", European Planning Studies, Vol. 19, No. 11, pp.1931-1950.

Gerardo, M. (2015), The deconstructed church: Understanding emerging Christianity, Oxford University Press, New York, NY.

Goodman, S. (2010), “Integration requirements for Integration's sake? Identifying, categorising and comparing civic integration policies", Journal of Ethics and Migration Studies, Vol. 36, No.5, pp.753772.

Ham, C. (2015), Place-based systems of care, King's Fund Publications, London, UK.

Hampshire County Council. (2016), Hampshire Strategic Infrastructure Statement. Strategic Planning. Hampshire County Council, Winchester, UK.

Hauerwas, S. (1981), A community of character, Notre Dame, London, UK.

Hausermann, S. (2012), The politics of Old and New Social Policies. In Bonoli, G.and Natali,D. (Eds.), The politics of the New Welfare State, Oxford university Press, Oxford, pp.111-134.

Hiroko, O., Yamaoka Y. and Hideshema, E. (2016), "How to support decision making of local government in prioritising policy menu responding to citizens' views". Business Information Processing, Vol. 250, pp.202-216.

Hughes, J. (2014), "After Temple? The recent renewal of Anglican social thought". In Brown, M. (Ed.), Anglican Social Theology Today. Church House Publishing, London, pp.74-101.

Jeffres, L. W., Bracken, C. C., Jian, G., and Casey, M. F. (2009), "The impact of third places on community quality of life", Applied Research in Quality of Life, Vol. 4, pp. 333-345.

Joseph Rowntree Foundation. (2016), Estate Regeneration Briefing for expert panel, available at: https://www.jrf.org.uk/report/estate-regeneration-briefing-expert-panel (accessed 12 June 2016).

Kirkpatrick, F. (2001), The ethics of community. Blackwell, Oxford, UK.

London Assembly. (2015), "Knock it Down or Do it Up? The challenge of estate regeneration", available at:

https://www.london.gov.uk/sites/default/files/gla migrate files destination/KnockltDownOrDoltU p 0.pdf (accessed 13 June 2016).

Mason, C., Barraket, J., Friel, S., O'Rourke, K. and Stenta, C-P. (2015), "Social innovation for the promotion of health equity", Health Promotion International, Vol. 30, Supp.2, pp.116-125.

Meads, G., Griffiths, F., Goode, S. and Iwami, M. (2007). “Lessons from local engagement in Latin American health systems". Health Expectations, Vol. 10, No. 4, pp.407-418. 
Myers, J. (1986), The English Settlements. Clarendon Press, Oxford, UK.

National Health Service (NHS) England. (2016), "Healthy new towns. Five Year Forward View news update", available at: https://www.england.nhs.uk/ourwork/innovation/healthy-new-towns/ (accessed 18 July 2016).

Novak, M. (2009), Issues in Aging, Pearson, Boston, USA.

Newlands, G. and Smith, A. (2010), Hospitable God: The transformation dream, Ashgate, Farnham, UK.

Oldenburg, R. (1989), The Great Good Place: Cafés, Coffee Shops, Community Centers, Beauty Parlors, General Stores, Bars, Hangouts and How They Get You Through the Day, Paragon House, New York, NY.

Pacione, M. (2004), "Household growth, housing demand and new settlements in Scotland". European Planning Studies, Vol. 12, No. 4, pp. 517-535.

Pawson, T. (2013), The science of evaluation: A realist manifesto, Sage, London, UK.

Popay, J., Whitehead M., Carr-Hill, R., Dibben C., Dixon, P., Halliday, E., Nazroo, J., Peart E., Povall, S., Stafford, M., Turner, J. and Walthery, P. (2015), The impact of inequalities of approaches to community engagement in the New Deal of Communities regeneration initiative: A mixed methods evaluation, Public Health Research, Vol. 3, No.12, available at:

http://www.journalslibrary.nihr.ac.uk/ data/assets/pdf file/0005/153590/FullReportphr03120.pdfAccessed 16.7.2016.

Ralph, N. (2015), GNSS 2015 Impact Briefing. Good Neighbours Support Service, Portsmouth, Hampshire.

Seidman, K. (2013), Coming home to New Orleans. Oxford University Press, New York, NY.

Straten, G., Friele, R. and Groenewegen, P. (2002), "Public trust in Dutch health care", Social Science and Medicine, Vol. 55, No.2, pp.227-234.

Statistical Bulletin (2015), Annual Mid-Year Estimates. Office for National Statistics, Newport, South Wales, available at: www.ons.gov.uk (accessed 12 July 2016).

Stephenson, W. (2015), What we're fighting for now is each other. Beacon Press, Boston, USA.

Taylor, N. (1998), Urban planning theory since 1945, Sage, London, UK.

The Winchester Deanery. (2016), "A fresh new look at Deanery Synod" http://www.winchesterdeanery.org.uk/uploads/7/6/1/9/76190881/cometodeanerysynod14april201 6.pdf (accessed 15 April 2016).

The Place-Based Commission. (2016), "Get well soon. Re-imagining place-based health". New Local Government Network and Collaborate, London. http://www.nlgn.org.uk/public/wpcontent/uploads/Get-Well-Soon FINAL.pdf (accessed: 17 May 2016). 
Tolbert, C. M., Irwin, M. D., Lyson, T. A., and Nucci, A. R. (2002), "Civic community in small-town America. How civic welfare is influenced by local capitalism and civic engagement", Rural Sociology, Vol. 67, pp. 90-113.

Tuttle, R. (1983), Someone out there needs me: A practical guide to relational Evangelism, Zondervan Publishing, Nashville.

Walshe, C., Algorta, G., Dodds, S., Hill, M., Ockenden, N., Payne, S. and Preston, N. (2016), “Protocol for the Endof-Life Social Action Study (ELSA): A randomised wait-list controlled trial and embedded qualitative case study evaluation assessing the causal impact of social action befriending services on end of life experience", BMC Palliative Care, Vol. 15. No.60, DOI 10.1186/S12904-016-0134-3, available at: https://www.ncbi.nlm.nih.gov/pmc/articles/PMC4944471/pdf/12904 2016 Article 134.pdf (accessed 22. September 2016).

Williams, J. (2005), "Sun, surf and sustainable housing - Cohousing, the California experience". International Planning Studies, Vol.10, No. 2, pp.145 - 177.

Williams, R. (2015), Faith in the public square, Bloomsbury Continuum, London, UK.

Winchester Diocesan Synod. (2015), "Mission Action Planning. Strategic Priorities", available at: http://www.winchester.anglican.org/about-us/strategic-priorities/ (accessed : 14 September 2016). 